\title{
Exchange Rate Volatility and Non-oil Exports in Nigeria: An Empirical Investigation
}

\author{
Musibau Hammed O*, Babatunde SA, Halimah AA and Hammed AY
}

Department of Economics, University of Ilorin, Nigeria

\begin{abstract}
The adoption of a flexible exchange rate system since 1986 in Nigeria has made the country witnessed varying rate of the naira vis-à-vis the U.S dollar. This paper examines exchange rate volatility with $\mathrm{ARCH}$ model and its various extensions (GARCH, TGARCH, and EGARCH) using quarterly exchange rate series from 1986q1 to 2014q4. The impact of exchange rate volatility on non-oil exports was also examined using Error Correction Model (ECM) with two different measures of volatility. The results obtained confirm the existence of exchange rate volatility and also found a significant negative effect on non-oil export performance in Nigeria. Therefore, the Nigerian government should ensure an appropriate policy mix that not only ensures a stable and realistic exchange rate but also conducive atmosphere for production and exportation.
\end{abstract}

Keywords: Non-oil export; Exchange rate volatility; Trade; ARCHtype Models

\section{Introduction}

It is the primary objective of any development aspired country to be buoyant in international trade. But the extent to which this could be achieved reckons on the ability of such country to expand and sustain exports. The fact still remains that in this globalised world, no nation can live absolute independence since all economies are directly or indirectly connected through assets or/and goods markets. This linkage is made possible through international trade and foreign exchange. An economy with more exports than imports will enjoy favourable balance of payment as it receives more than it pays in her international transactions with the rest of the world. Among the factors that determines the volume of international trade, exchange rate plays an important role because it directly affects domestic prices, profitability of traded goods and services, allocation of resources and investment decision. Stability of exchange rate is therefore required for better outcome of international trade and favourable balance of payment.

However, exchange rate volatility was experienced by most countries around the world after the exit of Bretton Wood system of fixed exchange rate regime in the 70s. The continuous increase in volatility of exchange rates over the years has been the source of concern for both researchers and policy makers around the globe [1]. This development affected economies of most developing countries especially those with mono product economy in which Nigeria is inclusive. Fluctuation of exchange rate makes international transaction risky such that riskaverse agents tend to reduce the export-import activities and reallocate production to domestic markets. Hooper and Kohlhagen [2] argue that higher exchange rate volatility leads to higher cost for risk-averse traders and less foreign trade. In corroboration, Panda and Mohanty [3] assert that high volatility in exchange rate usually have negative effect on price discovery, export performance and sustainability of current account balance. This is possible for country like Nigeria where the economy depends on the export of crude oil for survival. In this case, the economy is subjected to the vicissitudes and vagaries of the oil market such that shocks in international oil price were immediately felt in the domestic economy [4].

However, one major concern about the naira exchange rate over the study period is its instability. And since the exchange rate is an important factor in determining the value of exports of a country in the global market, there is need to examine its effect on the volume of Nigeria non-oil exports. Although Nigeria government has over the years engaged in international trade and has been designing trade and exchange rate policies to promote trade [5], but the extent to which these policies have been effective in promoting export has remained unascertained. This is because despite government efforts, the growth performance of Nigeria non-oil export has not been favourable. On this premise, this study investigates the effect of exchange rate volatility on non-oil exports in Nigeria for the periods 1986Q1-2014Q4.

The remaining part of the paper is organized as follows: section 4 focuses on literature review; section 5 presents the methodology, section 6 deals with the data analysis and discussion of results and section 7 concludes the study.

\section{Literature Review}

Exchange rate, the price of one currency in terms of another, is an important price in an open economy that influences the flows of goods, services and capital in any given economy [6]. Instability in exchange rate exerts strong pressure on the balance of payments, inflation and other macroeconomic variables. Hooper and Kohlhagen [2] assert that negative relationship exists between exchange rate volatility and volume of trade if economic agents are risk-averse. They argued that a riskaverse trader will experience decrease in the utility gains from the trade when exchange rate is volatile due to its negative effects on the profit, thus reduces the volume of international trade. However, the effect of exchange rate volatility on international trade depends on the attitudes of importers and exporters towards risk. If they are risk-loving agents, exchange rate volatility may exert positive effect on international trade and if they are risk-neutral no effect may be experienced. De Grauwe [7] was with the opinion that the risk-loving trader will export more

*Corresponding author: Musibau Hammed O, Department of Economics University of llorin, llorin, Nigeria, Tel: +23431221691; E-mail: agboolayusuf2007@gmail.com

Received April 10, 2017; Accepted April 18, 2017; Published April 28, 2017

Citation: Musibau Hammed O, Babatunde SA, Halimah AA, Hammed AY (2017) Exchange Rate Volatility and Non-oil Exports in Nigeria: An Empirical Investigation. J Glob Econ 5: 246. doi: 10.4172/2375-4389.1000246

Copyright: (C) 2017 Musibau Hammed O, et al. This is an open-access article distributed under the terms of the Creative Commons Attribution License, which permits unrestricted use, distribution, and reproduction in any medium, provided the original author and source are credited. 
goods due to high exchange rate volatility which may cause an increase in the total trade, while risk neutral traders will export fewer goods which may result to less export traded. He concluded that the impact of exchange rate volatility on exports may be positive or negative. Hericourt and Poncet [1] linked the severity or magnitude of negative effect on trade to the level of financial development, it is stronger for less financially developed country and weaker with high levels of financial development. It is therefore evident that volatility of exchange rate is the source of exchange rate risk and has serious implications on the volume of international trade, and consequently on the balance of payments.

However, high volatility of exchange rate experienced by most countries induced researchers to investigate the nature and extent of its impact on volume of trade [3]. While some found positive effects $[8,9]$, others found negative effects $[3,10,11]$. For instance, Shaikh and Hongbing [10] examined the impact of exchange rate volatility on trade flows for China, Pakistan and India using Autoregressive Distributive Lag (ARDL) model. Their results revealed a negative impact of exchange rate volatility on exports for Pakistan and India both in the short-run and long-run. The results for the China also revealed negative relationship in the short-run while positive relationship was revealed in the long-run. Panda and Mohanty [3] empirically examined the effect of exchange rate volatility on India's exports for the period 1970-2012. They used simple rolling standard deviation as a measure of exchange rate volatility and also found negative impact on exports. In 2012, Hericourt and Poncet [1] investigated the impart of real exchange rate volatility and financial constraints on trade for China covering the period 2000-2006. Their results revealed that high exchange rate volatility reduces exports. They conclude that the magnitude of the export-deterring effect depends on the extent of firms' financial vulnerability.

Ozturk and Kalyancu [12] empirically examined the impact of exchange rate volatility on the trade flows for six countries using Engle-Granger residual based cointegration technique. While positive significant effects were found for Turkey and Hungary, the results revealed negative significant effects for South Korea, Pakistan, Poland and South Africa. Asteriou et al. [13] examined the effects of exchange rate volatility on volume of trade for Mexico, Indonesia, Turkey and Nigeria. Using Autoregressive Distributive Lag (ADRL) bound testing approach, no significant relationship was found between exchange rate volatility and volume of trade (import and export) in the long-run. In the short-run, their results revealed a significant relationship between exchange rate and trade.

In the case of Nigeria, Akinlo and Adejumo [8] used Error Correction Mechanism to examine the impact of exchange rate volatility on non-oil exports. Their results revealed a significant positive effect on non-oil export in the long run and insignificant effect in the short-run. Aliyu [11] employed vector error correction model (VECM) to assess the impact of exchange rate volatility on non-oil export flows. His results revealed a negative significant effect of exchange rate volatility on non-oil exports in the long run. This is similar to the findings of Imoughele and Ismaila [14] who employed ECM model to examined the impact of exchange rate on non-oil export and found negative impact of exchange rate appreciation on non-oil export. Olufayo and Fagitem [15] employed Generalized Autoregressive Conditional Heteroskedasticity (GARCH) technique to measure the volatility and used seemingly unrelated regression (SUR) for the estimation. Their results revealed negative but insignificant impact on non-oil export. The inconclusive findings of studies on the subject matters has been ascribed to many reasons. While Nyahokwe and Ncwadi [16] attributed the difference in the empirical results to different measures of volatility, others linked it to aggregation bias [17] and level of financial market development $[1,18]$.

\section{Methodology}

\section{Model specification}

From the reviewed theoretical and empirical studies, many variables were identified as the major determinants of non-oil exports. Among the variables are: real gross domestic product, broad money supply, trade openness, terms of trade, and Exchange rate volatility. Expressing these in mathematical form gives;

noex: $\beta_{0}+\beta_{1} r g d p_{t}+\beta_{2} m 2_{t}+\beta_{3}$ top ${ }_{t}+\beta_{4}$ tot $+\beta_{5}$ excrv $_{t}+u_{t}$

Where;

noex: $_{t}$ Non-oil Exports at time $\mathrm{t}$

$r g d p_{t}:$ Real Gross Domestic Product at time t

$m 2$ : Broad Money Supply at time $\mathrm{t}$

top: Trade Openness at time $\mathrm{t}$

tot $_{t}$ : Terms of Trade at time $\mathrm{t}$

excrv ${ }_{t}$ : Exchange rate volatility at time $\mathrm{t}$

$u_{t}$ : Error Term

To reduce the wide range in volume of our variables, all the variables except exchange rate volatility were logged and equation 1 becomes:

$$
\operatorname{lnnoex~}_{t}=\beta_{0}+\beta_{1} \operatorname{lnrgdp_{t}}+\beta_{2} \operatorname{lnm} 2_{t}+\beta_{3} \ln t o p_{t}+\beta_{4} \ln t o t_{t}+\beta_{5} \operatorname{excrv}_{t}+u_{t}(2)
$$

The error correction representation of the model above is therefore specified as:

$$
\begin{aligned}
& \Delta \operatorname{lnnoex}=\beta_{0}+\beta_{1} \Delta \operatorname{lnrgdp_{\mathrm {t}}}+\beta_{2} \Delta \operatorname{lnm} 2_{\mathrm{t}}+\beta_{3} \Delta \operatorname{lntop_{\mathrm {t}}}+\beta_{4} \Delta \ln \text { tot } \mathrm{t}_{\mathrm{t}}+ \\
& \beta_{5} \Delta \operatorname{exctv}_{\mathrm{t}}+\beta_{6} \mathrm{ect}_{\mathrm{t}-1}+\mathrm{V}_{\mathrm{t}}
\end{aligned}
$$

Where $\Delta$ is the first difference operator and ect $t_{t-1}$ is the error correction term. The a-priori expectations are: $\beta_{1}, \beta_{2}, \beta_{3}, \beta_{4}>0 ; \beta_{5}, \beta_{6}<0$.

\section{Estimation techniques}

Autoregressive Conditional Heteroskedascity (ARCH) method and its other extensions such as GARCH, TGARCH and EGARCH were used to test the volatility of exchange rate. The ARCH-LM test proposed by Breusch-Pagan [19], which also consistent with Engle [20] ARCH-LM test was used to test for the ARCH effect so as to determine the existence of volatility in the naira-dollar exchange rate. The equation for the estimate is:

$$
R_{t}=\alpha+\beta_{1} R_{t-1}+\varepsilon_{t}
$$

Where Rt is the return on the series.

The squared of estimated residual $\left(\varepsilon_{t}^{2}\right)$ obtained in equation 4 is then regressed on its lag as follows:

$$
\varepsilon_{\mathrm{t}}^{2}=\Upsilon_{0}+\Upsilon_{1} \varepsilon_{\mathrm{t}}^{2}-1+\mathrm{v}_{\mathrm{t}}
$$

The null hypothesis Ho: $\Upsilon_{1}=0$----- No ARCH effect

Alternative hypothesis $\mathrm{H}_{1}: \gamma_{1} \neq 0$----- Presence of ARCH effect

The null hypothesis of no ARCH effects is rejected if the probability value of this test is less than any of the convention statistical significance 
levels $(10 \%, 5 \%$, and $1 \%)$. The rejection of the null hypothesis implies the presence of $\mathrm{ARCH}$ effect. The presence of volatility in the exchange rate required estimations of ARCH-type models.

The ARCH model introduced by Engle [20] was employed in this study. The model suggests that the variance of the residuals at time $t\left(\varepsilon_{t}\right)$ depends on the square of error terms from past periods hence the variance is not constant. In developing an ARCH model, two distinct specifications are considered - one for the conditional mean and the other for the conditional variance. An ARCH (1) model is thus specified below;

\section{Mean Equation:}

$\mathrm{Y}_{\mathrm{t}}=\mathrm{X}_{\mathrm{t}}^{1} \theta+\varepsilon_{\mathrm{t}}$

Variance Equation

$$
\delta^{2}=\alpha+\beta \varepsilon^{2}{ }_{\mathrm{t}-1}+\mathrm{U}_{\mathrm{t}}
$$

Also, considered in this study is the General Autoregressive Conditional Heteroskedascity (GARCH) model developed by Bollerslev [21]. It is an extension of Engle's ARCH model. It captures the effect of variance on volatile time series which ARCH model does not. The mean equations in both ARCH and GARCH are the same but the conditional variance equations differ. The estimation procedure for GARCH is the same in ARCH model; the only difference is the conditional variance equation which is stated below;

$$
\delta^{2}{ }_{\mathrm{t}}=\alpha+\beta_{1} \varepsilon_{\mathrm{t}-1}^{2}+\beta_{2} \delta^{2}{ }_{\mathrm{t}-1}+\mathrm{U}_{\mathrm{t}}
$$

Where; $\varepsilon_{t-1}^{2}$ is the ARCH term and $\delta_{t-1}^{2}$ is the GARCH term. The closer the sum of the coefficients to 1 , the slower the mean reverting and the closer the sum to 0 , the faster the mean reverting.

The Threshold GARCH (TGARCH) and Exponential GARCH (EGARCH) model introduced by Zakoian [22] and Nelson [23] respectively were also considered for estimation in this study. These models capture asymmetric or leverage effect not accounted for by $\mathrm{ARCH}$ and GARCH models. This asymmetric relationship is called leverage effect, and describes how a negative shock causes volatility to rise more than if a positive shock with the same magnitude had occurred. The specification for the conditional variance equations is thus stated as;

$$
\delta_{t}^{2}=\alpha+\sum_{i=1}^{p} \beta_{i} \varepsilon_{t-i}^{2}+\sum_{j=1}^{q} \beta_{j} \delta_{t-j}^{2}++\sum_{h=1}^{r} \gamma_{h} \varepsilon_{t-h}^{2} \bar{I}_{t-h}
$$

Where; $\overline{\mathrm{I}}_{\mathrm{t}}=1$ if $\varepsilon_{\mathrm{t}}=0$ and 0 otherwise. Good news has an impact of $\beta_{i}$ while bad news has an impact of $\beta_{i}+\gamma_{i}$. If $\gamma_{i}>0$, bad news increases volatility and that means there is leverage effect.

$$
\ln \left(\delta_{t}^{2}\right)=\mu_{0}+\mu_{1} \sqrt{\varepsilon^{2} \mathrm{t}-1 / \delta^{2} \mathrm{t}-1} \phi \sqrt{\varepsilon^{2} \mathrm{t}-1 / \delta^{2} \mathrm{t}-1}+\theta \ln \left(\delta_{t-1}^{2}\right)
$$

The presence of leverage effect can be tested by the hypothesis that $\phi<0$. If $\phi=0$ there is no asymmetric effect.

\section{Sources and measurement of data}

The study employs quarterly time series data covering the period from 1986Q1 to 2014Q4. The type of data used in this study is secondary and are sourced from the Central Bank of Nigeria (CBN) [24] statistical bulletin and International Monetary Fund (IMF). Trade openness is measured by the sum of non-oil export and import divided by the GDP. Terms of trade was proxy by the ratio of Nigeria's consumer price index and the US's producer price index. While exchange rate volatilityl is a measure of the rate of change of real effective exchange rate, exchange rate volatility 2 is computed using standard deviation of the growth rate of real effective exchange rate.

\section{Data Analysis and Discussion of Results}

The ARCH-LM test was conducted to ascertain the existence of volatility in exchange rate, the results of the test were presented in Table 1 . The results show that the probability values for both F-statistic and R-squared indicate the existence of $\mathrm{ARCH}$ effect in exchange rate which means that exchange rate was volatile.

Haven established the presence of volatility in naira-dollar exchange rate, $\mathrm{ARCH}$-type models were estimated and the results were presented in Table 2. The coefficient of ARCH (0.6082) in the model is statistically insignificant since the probability value is more than 5 percent. This means previous volatility of exchange rate is not a significant variable to explain the current value of exchange rate. However, the coefficient of GARCH (0.5603) is statistically significant indicating the presence of GARCH effect. This indicates that news about volatility from previous periods have an explanatory power on current volatility. This is similar to the result found by Adeoye and Atanda [25] and Olufayo and Fagite [15]. The sum of the coefficients of ARCH and GARCH (0.5399) indicates slow mean reverting shock.

The result of TGARCH shows that thresholds are not significant in the determination of asymmetric effect in the volatility of exchange rate. However, the EGARCH gives a negative asymmetry coefficient $(-0.9401)$ which is significant at 5 percent. This indicates that positive shocks increase volatility of exchange rate in Nigeria more than negative shocks of the same magnitude. Thus, good news has more potentials of increasing exchange rate volatility than bad news in the Nigerian foreign exchange market. The EGARCH model appears to be the best since it gives the smallest value of AIC (-2.2149) and SIC (-2.0709).

To be sure that the volatility of the series has been adequately captured in our models, post estimation test was conducted for all the ARCH-type models used in this study. The results are presented in Table 3 below.

The results revealed that the volatility of the series has been captured in our models since all probability values are greater than any of the conventional significance level $(1 \%, 5 \%$ or $10 \%)$.

\begin{tabular}{|c|c|c|}
\hline \multicolumn{3}{|c|}{ Ho: No ARCH Effect } \\
\hline F-Statistic & 1629.655 & Prob. F (0.0000) \\
\hline Observed R-squared & 107.5430 & Prob. Chi-square (0.0000) \\
\hline & Table 1: ARCH LM Test.
\end{tabular}

\begin{tabular}{|c|c|c|c|c|}
\hline Variables & ARCH (1,1) & GARCH (1,1) & TGARCH & EGARCH \\
\hline \multicolumn{5}{|c|}{ Mean Equation } \\
\hline Constant & $0.0359(0.4266)$ & $0.0394(0.5887)$ & $0.0327(0.6425)$ & $-0.0127(0.0000)$ \\
\hline EXCR (-1) & $0.0617(0.8385)$ & $0.0336(0.9264)$ & $0.0324(0.9264)$ & $0.0814(0.0000)$ \\
\hline \multicolumn{5}{|c|}{ Variance Equation } \\
\hline Constant & $0.0191(0.0000)$ & $0.0160(0.0685)$ & $0.0158(0.0663)$ & $-0.2440(0.0000)$ \\
\hline ARCH (1) & $0.6082(0.0528)$ & $-0.0204(0.2945)$ & $-0.0194(0.0000)$ & $0.1814(0.0000)$ \\
\hline GARCH (1) & - & $0.5603(0.0171)$ & $0.5535(0.0179)$ & $0.8897(0.0000)$ \\
\hline THRESHOLD(1) & - & - & $-0.3532(0.8957)$ & \\
\hline ASSYMETRY(1) & - & - & - & $-0.9401(0.0000)$ \\
\hline \multicolumn{5}{|c|}{ Diagnostic Test } \\
\hline AIC & -0.8744 & -0.8269 & -0.8346 & -2.2149 \\
\hline SIC & -0.7784 & -0.7069 & -0.6905 & -2.0709 \\
\hline HQC & -0.8354 & -0.7782 & -0.7761 & -2.1565 \\
\hline
\end{tabular}

Note: ( ) denote probability value.

Table 2: Estimates from Arch-type models. 
The results of the unit root test were presented in Table 4 . The Augmented Dickey Fuller (ADF) test revealed that all the variables were stationary at first difference. That is, all the variables were integrated of order one $\mathrm{I}(1)$. The study went further and tested for the existence of long-run relationship between the dependent variable and independent variables using Johansen co-integration approach. The estimated results, as presented in Table 5, indicated that the series had two co-integrating equations at $5 \%$ level of significance. This implies that all variables are co-integrated and follow a common long run path. Given that a co-integrating relationship exists among the selected variables, an error correction model (ECM) was estimated, and the results were presented in Table 6.

The result in Table 6 is the parsimonious regression results after elimination of the highest insignificant variables one after the other using the Akaike Information Criterion (AIC). Real gross domestic product came out with expected sign but statistically insignificant in both models. The broad money supply appeared with negative signs and statistically significant in model 2 . This supports the findings of Olufayo and Fagite [15] who also found negative impact on non-oil export.

In both models (measures of volatility) trade openness has positive signs and exert a strong significant impact on non-oil exports as one percent increase in this variable will increase the value of non-oil exports by approximately 70 percent while terms of trade have negative signs and statistically insignificant in determining non-oil export.

Exchange rate volatility (excrv1) has a negative and significant effect on non-oil exports while the second measure of volatility $\left(\right.$ excrv $\left.{ }_{t}\right)$

\begin{tabular}{|c|c|c|c|c|}
\hline \multicolumn{5}{|c|}{ Ho: No ARCH Effect } \\
\hline & ARCH (1, 1) & GARCH (1, 1) & TGARCH & EGARCH \\
\hline F-Statistic & 0.0168 & 0.0017 & 0.0162 & 0.1543 \\
\hline Prob. Value & 0.8913 & 0.9668 & 0.8988 & 0.6953 \\
\hline Obs. R-squared & 0.0171 & 0.0018 & 0.0165 & 0.1568 \\
\hline Prob. Value & 0.8961 & 0.9664 & 0.8977 & 0.6921 \\
\hline \multicolumn{5}{|c|}{ Table 3: ARCH LM Test. } \\
\hline
\end{tabular}

\begin{tabular}{|c|c|c|c|c|}
\hline Variables & ADF Statistics & $\mathbf{5 \%}$ Critical Value & Prob. Value & Remark \\
\hline Innoex $_{t}$ & -0.6069 & -2.8882 & 0.8636 & Not Stationary \\
\hline$\Delta\left(\right.$ Innoex $\left._{t}\right)$ & -5.1324 & -2.8882 & 0.0000 & Stationary I(1) \\
\hline Inrgdp $_{t}$ & -0.3528 & -3.4524 & 0.9881 & Not Stationary \\
\hline$\Delta$ Inrgd $\left._{t}\right)$ & -5.7821 & -3.4524 & 0.0000 & Stationary I(1) \\
\hline Inm2 $_{t}$ & -1.3065 & -3.4494 & 0.8814 & Not Stationary \\
\hline$\Delta\left(\right.$ Inm2 $\left._{t}\right)$ & -11.4898 & -3.4497 & 0.0000 & Stationary I(1) \\
\hline Intop $_{t}$ & -1.7074 & -3.4528 & 0.7413 & Not Stationary \\
\hline$\Delta$ (Intop $\left._{t}\right)$ & -6.9895 & -3.4528 & 0.0000 & Stationary I(1) \\
\hline Intot $_{t}$ & -1.9059 & -3.4497 & 0.6430 & Not Stationary \\
\hline$\Delta\left(\right.$ Intot $\left._{t}\right)$ & -4.5456 & -3.4497 & 0.0020 & Stationary I(1) \\
\hline excrv $_{t}$ & -0.5013 & -2.8867 & 0.8859 & Not Stationary \\
\hline$\Delta\left(\right.$ excr $\left._{t}\right)$ & -9.6453 & -2.8870 & 0.0000 & Stationary I(1) \\
\hline
\end{tabular}

Table 4: Unit Root Test (ADF).

\begin{tabular}{|c|c|c|c|c|}
\hline $\begin{array}{c}\text { Hypothesized } \\
\text { No of CE(s) }\end{array}$ & Eigen Value & Trace Statistic & $\mathbf{5 \%}$ CV & P Value \\
\hline None & 0.3160 & 130.4287 & 117.7082 & 0.0062 \\
\hline At most 1 & 0.2454 & 90.1639 & 88.8038 & 0.0397 \\
\hline At most 2 & 0.2213 & 60.3182 & 63.8761 & 0.0961 \\
\hline At most 3 & 0.1561 & 33.8041 & 42.9153 & 0.2975 \\
\hline At most 4 & 0.0966 & 15.8180 & 25.8721 & 0.5072 \\
\hline At most 5 & 0.0465 & 5.0516 & 12.5180 & 0.5890 \\
\hline
\end{tabular}

Table 5: Co-integration Test (Trace).

\begin{tabular}{|c|c|c|}
\hline Regressors & Model 1 & Model 2 \\
\hline Constant & $0.0318(0.1151)$ & $0.0352(0.0829)$ \\
\hline$\Delta / n r g d p_{t}$ & $0.0662(0.5752)$ & $0.0640(0.5904)$ \\
\hline$\Delta / n m 2_{t}$ & $-0.3294(0.0782)$ & $-0.3693(0.0490)^{\star \star}$ \\
\hline$\Delta /$ ntop $_{t}$ & $0.6951(0.0000)^{*}$ & $0.6888(0.0000)^{\star}$ \\
\hline$\Delta /$ ntot $_{t}$ & $-0.1041(0.7187)$ & $-0.1181(0.6855)$ \\
\hline$\Delta e x c r v 1_{t}$ & $-0.0708(0.0182)^{\star *}$ & \\
\hline$\Delta e x c r v 2_{t}$ & & $-0.0966(0.0577)$ \\
\hline$\Delta / n n o e x_{t-1}$ & $0.5081(0.0000)^{*}$ & $0.4726(0.0000)^{*}$ \\
\hline$\Delta / n t o p_{t-1}$ & $-0.4373(0.0000)^{*}$ & $-0.4091(0.0001)^{*}$ \\
\hline$\Delta /$ nnoex $_{t-2}$ & $0.1212(0.0732)$ & $0.1222(0.0728)$ \\
\hline$e c t_{t-1}$ & $-0.1453(0.0000)^{*}$ & $-0.1463(0.0000)^{*}$ \\
\hline $\mathrm{R}^{2}$ & 0.5736 & 0.5676 \\
\hline DW & 2.1801 & 2.1580 \\
\hline F Statistic & $14.6480(0.0000)$ & $14.2953(0.0000)$ \\
\hline $\mathrm{AIC}$ & -1.2934 & -1.2795 \\
\hline SIC & -1.0451 & -1.0312 \\
\hline HQC & -1.1927 & -1.1788 \\
\hline
\end{tabular}

Source: Authors' computation (2016). The probability values are in parentheses ( ) ${ }^{*}$ and ${ }^{* *}$ indicate significance at $1 \%$ and $5 \%$ levels respectively.

Table 6: Parsimonious Regression Results.

was also negative but not significant at 5 percent level of significance (adopted level of significance). The result for the first measure of volatility (excrv1 $)_{t}$ supports the findings of Imoughele and Ismaila [14] and Aliyu [11] while the second measure (excrv2 ${ }_{t}$ ) supports the findings of Olufayo and Fagite [15] who found an insignificant negative impact of exchange rate volatility on non-oil export. Thus, varying significant impact might be attributed to the difference in measurement employed by different studies. Non-oil export in previous period was found to be positively and significantly impacting non-oil export in current period while trade openness in previous period was found to have a negative and significant impact on non-oil export value in current period.

The error-correction term, ect $t_{t-1}$ appears with a statistically significant coefficient and displays the appropriate (negative) sign. This finding supports the validity of an equilibrium relationship among the variables in the co integrating equation. The result shows that a deviation from long run equilibrium level in current period is corrected by about 15 per cent in the next quarter for the result of both measures. This is a sign that the model is a non-spurious regression. The estimated long run result in Table 6 shows that at $1 \%$ level of significance the variables collectively influence the variation of non-oil export as show by the p-value of F-statistic (0.0000). Also, the value of $\mathrm{R}$-squared (0.5676 and 0.5736) shows that the independent variables used in the model jointly accounted for about 57 per cent of the total variation in non-oil export volume.

\section{Conclusion}

It is evident from the results of this study that exchange rate is volatile and has negative significant impact on non-oil exports in Nigeria. This could be attributed to the under developed financial system and over reliance on crude oil as major export product which exposed the economy to external shocks that caused the present economic crisis. The study concludes that collaborative efforts by all agents are required in ensuring an enabling environment that will support current economic diversification in the face of dwindling fortunes of crude oil. Government needs to adopt selective credit control so as to channel funds to the productive sectors of the economy, which will increase production for local consumption and export. Restrictive policy is also recommended to reduce pressure on foreign currency. If these are 
Citation: Musibau Hammed O, Babatunde SA, Halimah AA, Hammed AY (2017) Exchange Rate Volatility and Non-oil Exports in Nigeria: An Empirical Investigation. J Glob Econ 5: 246. doi: 10.4172/2375-4389.1000246

Page 5 of 5

properly implemented, imports will reduce, volatility in exchange rate will reduce and export will rise.

\section{References}

1. Hericourt J, Poncet $S$ (2012) Exchange rate volatility is a problem for trade... especially when financial development is low. VOX CEPR'S Policy Portal.

2. Hoope P, Kohlhagen S (1978) The effect of exchange rate uncertainty on the prices and volume of international trade. Journal of International Economics 8: 483-511.

3. Panda S, Mohanty RK (2015) Effects of exchange rate volatility on exports: Evidence from India. Economic Bulletin 35: 305 - 312.

4. Omojimite BU, Akpokodje G (2010) The impact of exchange rate reforms on trade performance in Nigeria. Journal of Social Science 23: 53-62.

5. Adewuyi AO (2005) Trade and exchange policy reform and export performance in Nigeria. Nigeria Economic Society (NES).

6. Fahrettin $Y(2001)$ Choice of exchange rate regimes and developing countries. The World Bank.

7. De Grauwe $P$ (1988) Exchange rate variability and the slowdown of growth of international trade. IMF Staff Papers 35: 63-84.

8. Akinlo AE, Adejumo VA (2014) Exchange rate volatility and non-oil exports in Nigeria: 1986 - 2008. International Business and Management 9: 70-79.

9. Broll U, Eckwert B (1999) Exchange rate volatility and international trade. Southern Economic Journal 66: 178-185.

10. Shaikh SA, Hangbing $O$ (2015) Exchange rate volatility and trade flows: Evidence from China, Pakistan and India. International Journal of Economics and Finance 7: 121-127.

11. Aliyu SU (2009) Exchange rate volatility and export trade in Nigeria. MPRA paper.

12. Ozturk I, Kalyancu $H$ (2009) Exchange rate volatility and trade: An empirical investigation from cross-country comparison. African Development Review 21 499-513.
13. Asteriou D, Masatci K, Pilbeam K (2016) Exchnage rate volatility and international trade: International evidence from the MINT countries. Economics Modelling 58: 133-140.

14. Imoughele LE, Ismaila M (2015) The impact of exchange rate on Nigerian non oil exports. International Journal of Academic in Research Accounting, Finance and Management Sciences 5: 190-198.

15. Olufayo MB, Fagite BA (2014) Exchange rate volatility and sectoral export of Nigeria: Case of oil and non-oil sectors. Journal of Economics and Sustainable Development 5: 66-75.

16. Nyahokwe O, Ncwadi R (2013) The impact of exchange rate volatility on South African exports. Mediterranean Journal of Social Sciences 4: 507-513.

17. Broda C, Romalis J (2010) Identifying the relationship between trade and exchange rate volatility, NBER chapters in: Commodity price and markets. East Asia Seminar of Economics 20: 79-110.

18. Grier KB, Smallwood AD (2007) Uncertainty and export performance: Evidence from 18 countries. Journal of Money, Credit and Banking 39: 965-979.

19. Breusch TS, Pagan AD (1979) A simple test for heteroscedasticity and random coefficient variation. Econometrica 47: 1287-1294.

20. Engle RF (1982) Autoregressive conditional heteroscedasticity with estimates of the variance of UK inflation. Econometrica 50: 987-1007.

21. Bollerslev T (1986) Generalised autoregressive conditional heteroscedasticity. Journal of Econometrics 31: 307-327.

22. Zakoian JM (1994) Threshold heteroskedastic models. Journal of Economic Dynamics and control 18: 931-955.

23. Nelson DB (1991) Conditional heteroskedasticity in asset returns: A new approach. Econometrica 59: 347-370.

24. Central Bank of Nigeria (2014) Statistical Bulletin. Abuja: Central Bank of Nigeria $(\mathrm{CBN})$

25. Adeoye BW, Atanda AA (2011) Exchange rate volatility in Nigeria: Consistency, Persistence, Severity analyses. CBN journal of applied statistics 2: 29-49. 